\title{
NEW REPORT OF DICHOTOMOSIPHON TUBEROSUS (A.BR.) ERNST AND VAUCHERIA SESSILIS D.C. OF THE FAMILY VAUCHERIACEAE FROM HOOGHLY DISTRICT, WEST BENGAL, INDIA
}

\author{
Sankar Narayan Sinha and Nilu Halder \\ Department of Botany, University of Kalyani \\ Kalyani 741235, West Bengal, India \\ Email: sinhasn62@yahoo.co.in
}

\begin{abstract}
The present work deals with the morpho-taxonomic description of two species namely Dichotomosiphon tuberosus (A.Br.) Ernst and Vaucheria sessilis (Vauch.) D.C. of the family Vaucheriaceae under the order Heterosiphonales belonging to the class Xanthophyceae for the first time explored from Hooghly district, West Bengal, India. The two taxa constitute new record for the aforesaid district.
\end{abstract}

Key words: Taxonomic description, Vaucheriaceae, Hooghly district.

\section{INTRODUCTION}

In India, early works on taxonomic description of Dichotomosiphon Ernst and Vaucheria D.C. were carried out by Chohan and Patel (1957), Sharma and Moghe (1957), Singh and Chowdhary (1973), Sarma (1973), Sarma and Chapman (1975), Verma and Verma (1978), Sinha and Srivastava (1980), Jha and Kaushal (1983), Pal and Santra (1984), Srivastava and Srivastava (1984), Khan (1985), Srivastava et al. (1987), Sarma and Rattan (1990), Ampili and Panikkar (1994), Mukhopadhyay and Pal (2004) and Dey (2007).

Since the two fresh water algal species belonging to Vaucheriaceae have not been explored earlier from the Hooghly district, W.B., the present work would be helpful for documenting these species to know the biodiversity of Xanthophyceaen species in the district.

\section{MATERIALS AND METHODS}

Algal samples were collected in sterilized glass containers from different aquatic bodies viz. pond at Tribeni $\left(22.99^{\circ} \mathrm{E}\right.$ and $\left.88.40^{\circ} \mathrm{N}\right)$, Balarambati $\left(22.82^{\circ} \mathrm{E}\right.$ and $\left.88.25^{\circ} \mathrm{N}\right)$, Khal (i.e., canal) at Khamargachi $\left(23.05^{\circ} \mathrm{N}\right.$ and $\left.88.25^{\circ} \mathrm{E}\right)$, canal at Behula $\left(23.18^{\circ} \mathrm{E}\right.$ and $\left.88.42^{\circ} \mathrm{N}\right)$ and rice field at Chinsurah $\left(22.90^{\circ} \mathrm{E}\right.$ and $\left.88.39^{\circ} \mathrm{N}\right)$ of Hooghly district (Fig. 1). Physicochemical parameters of these water bodies were measured. Detail studies of algae were made by examining the specimens under Olympus microscope (Model$\mathrm{CH} 20 \mathrm{i})$ for determination of species. Samples were preserved in $4 \%$ formalin. Identification of different taxa was accomplished with the help of authentic literature and monograph (Venkataraman 1961, Verma and Verma 1978, Ampili and Panikkar 1994, Dey 2007). 
Table 1. Physicochemical characteristics of different aquatic bodies in different months of collection (Mean \pm SE)

\begin{tabular}{|c|c|c|c|c|c|c|c|c|c|}
\hline \multirow[t]{2}{*}{ Parameters } & \multicolumn{3}{|c|}{ Pond water at Tribeni } & \multicolumn{3}{|c|}{ Canal water at Khamargachhi } & \multicolumn{3}{|c|}{ Pond water at Balarambati } \\
\hline & Jan. 2011 & Feb. 2011 & $\begin{array}{l}\text { Mar. } \\
2011\end{array}$ & Jan. 2011 & Feb. 2011 & $\begin{array}{l}\text { Mar. } \\
2011\end{array}$ & Jan. 2011 & Feb. 2011 & $\begin{array}{l}\text { Mar. } \\
2011\end{array}$ \\
\hline $\mathrm{pH}$ & $7.6 \pm 0.02$ & $7.7 \pm 0.04$ & $7.7 \pm 0.02$ & $7.3 \pm 0.02$ & $7.2 \pm 0.01$ & $7.5 \pm 0.03$ & $7.2 \pm 0.02$ & $7.3 \pm 0.02$ & $7.3 \pm 0.02$ \\
\hline $\begin{array}{l}\text { Temperature } \\
\left({ }^{0} \mathrm{C}\right)\end{array}$ & $19.5 \pm 0.11$ & $24.0 \pm 0.53$ & $29.0 \pm 0.51$ & $19.0 \pm 0.21$ & $20.5 \pm 0.3$ & $24.0 \pm 0.36$ & $19.0 \pm 0.11$ & $19.5 \pm 0.53$ & $20.5 \pm 0.53$ \\
\hline $\mathrm{DO}(\mathrm{mg} / \mathrm{L})$ & $8.4 \pm 0.06$ & $9.0 \pm 0.11$ & $8.2 \pm 0.07$ & $7.6 \pm 0.28$ & $7.8 \pm 0.31$ & $7.2 \pm 0.28$ & $7.4 \pm 0.08$ & $7.6 \pm 0.11$ & $7.8 \pm 0.12$ \\
\hline $\mathrm{NO}_{3}-\mathrm{N}$ & $0.08 \pm 0.02$ & $0.17 \pm 0.04$ & $0.3 \pm 0.04$ & $0.12 \pm 0.03$ & $0.1 \pm 0.02$ & $0.12 \pm 0.03$ & $0.09 \pm 0.03$ & $0.12 \pm 0.02$ & $0.15 \pm 0.04$ \\
\hline $\mathrm{PO}_{4}$ & $0.16 \pm 0.02$ & $0.12 \pm 0.03$ & $0.09 \pm 0.01$ & $0.08 \pm 0.01$ & $0.12 \pm 0.05$ & $0.15 \pm 0.06$ & $0.08 \pm 0.02$ & $0.10 \pm 0.03$ & $0.12 \pm 0.04$ \\
\hline
\end{tabular}

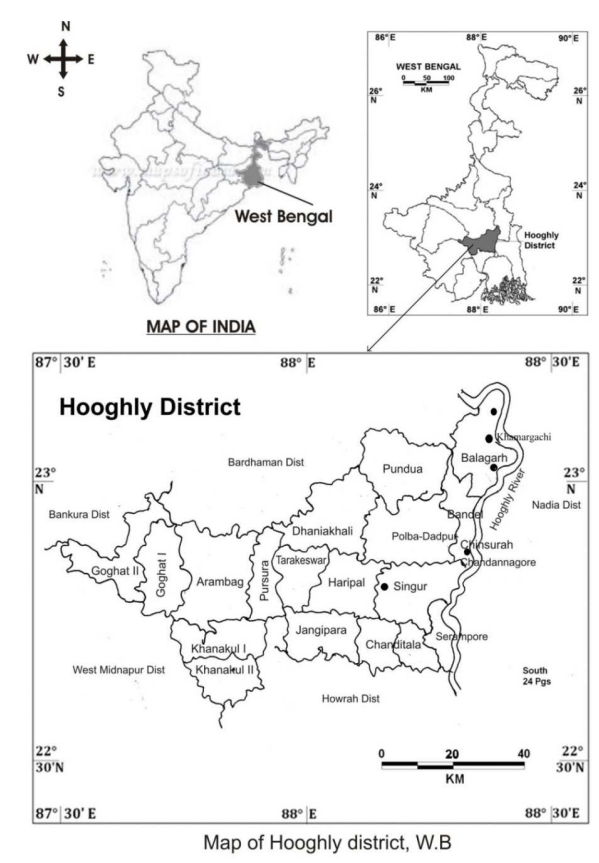

Fig. 1. Map of Hooghly district, West Bengal.

\section{RESULTS AND DISCUSSION}

The physico-chemical parameters of different water bodies studied are given in Table 1. The $\mathrm{pH}$ in all the aquatic ecosystems studied was alkaline in nature. Presence of phosphate and nitrate nitrogen along with the physicochemical parameters favoured the growth of algae in these waters. Two newly recorded Xanthophyceaen species namely Dichotomosiphon tuberosus (A.Br.) Ernst and Vaucheria sessilis (Vauch.) D.C. belonging to the order Heterosiphonales of 50
Vaucheriaceae were morpho-taxonomically described from Hooghly district, West Bengal with ecological note and significance for the first time. Each specimen was provided with its currently accepted author (s)' name.

\section{Key to the genera}

1a. Thallus di- or tri-chotomously branched with constrictions at the point of branching; reserve food material starch------1. Dichotomosiphon Ernst b. Thallus not so, but more or less irregularly branched; reserve food material not starch

2. Vaucheria DC.

Genus: 1. Dichotomosiphon Ernst

Order: Heterosiphonales

Family: Vaucheriaceae

Genus: 1. Dichotomosiphon Ernst

1. Dichotomosiphon tuberosus (A.Br.) Ernst (Pl. 1,

Figs. 1a, 1b and 3.)

Vaucheria tuberosa A.Br. 1856.

Ernst in Beih. Bot. Centralbl. 13: 115. 1902.

Heering in Süsswasserflora 7: 96. figs. 93, 94. 1921.

Brown, Trans. Amer. Mic. Soc. 48: 102. pl. 20. figs. 38, 39. 1929.

Randhawa, J. Indian bot. Soc. 21: 265. figs. 4. 1942.

Venkataraman, Vaucheriaceae 38. figs. 18 a-f. 1961.

Verma and Verma, in Phykos. 17: 59. figs.1-7. 1978.

ECOPRINT VOL 21，2014 
Description: Thallus aquatic, monoecious, filamentous, siphon like, di or tri-chotomously branched with constrictions at and in between dichotomies; filaments 73.1-307.2 $\mu \mathrm{m}$ long and 73.1-80.4 $\mu \mathrm{m}$ broad; constrictions 58.5-65.8 $\mu \mathrm{m}$ broad; oogonium spherical, solitary without a beak, slightly depressed near attachment, 277.9-279.7 $\mu \mathrm{m}$ broad; usually one oogonium in between two antheridia at the terminal end of fruiting branches, sometimes one oogonium by the side of one antheridium; oospore globose, not filling the oogonium, light dark- green in colour, 252.5-265.8 $\mu \mathrm{m}$ broad; antheridium cylindrical or club shaped, slightly undulating arising from terminal branches,131.6-193.8 $\mu \mathrm{m}$ long and 58.5-60.3 $\mu \mathrm{m}$ broad; chloroplasts numerous, small disc-shaped without pyrenoids.

Habitat: Grows on sandy mud of different types of fresh water habitats viz. pond at Tribeni, khal (canal) at Khamargachi, canal at Behula and rice field at Chinsurah, West Bengal, India.

Collection No: 814, 1025

Date: 03.01.2011, 10.03.2011

Significance: Primary producer and a component of food chain in aquatic habitat.

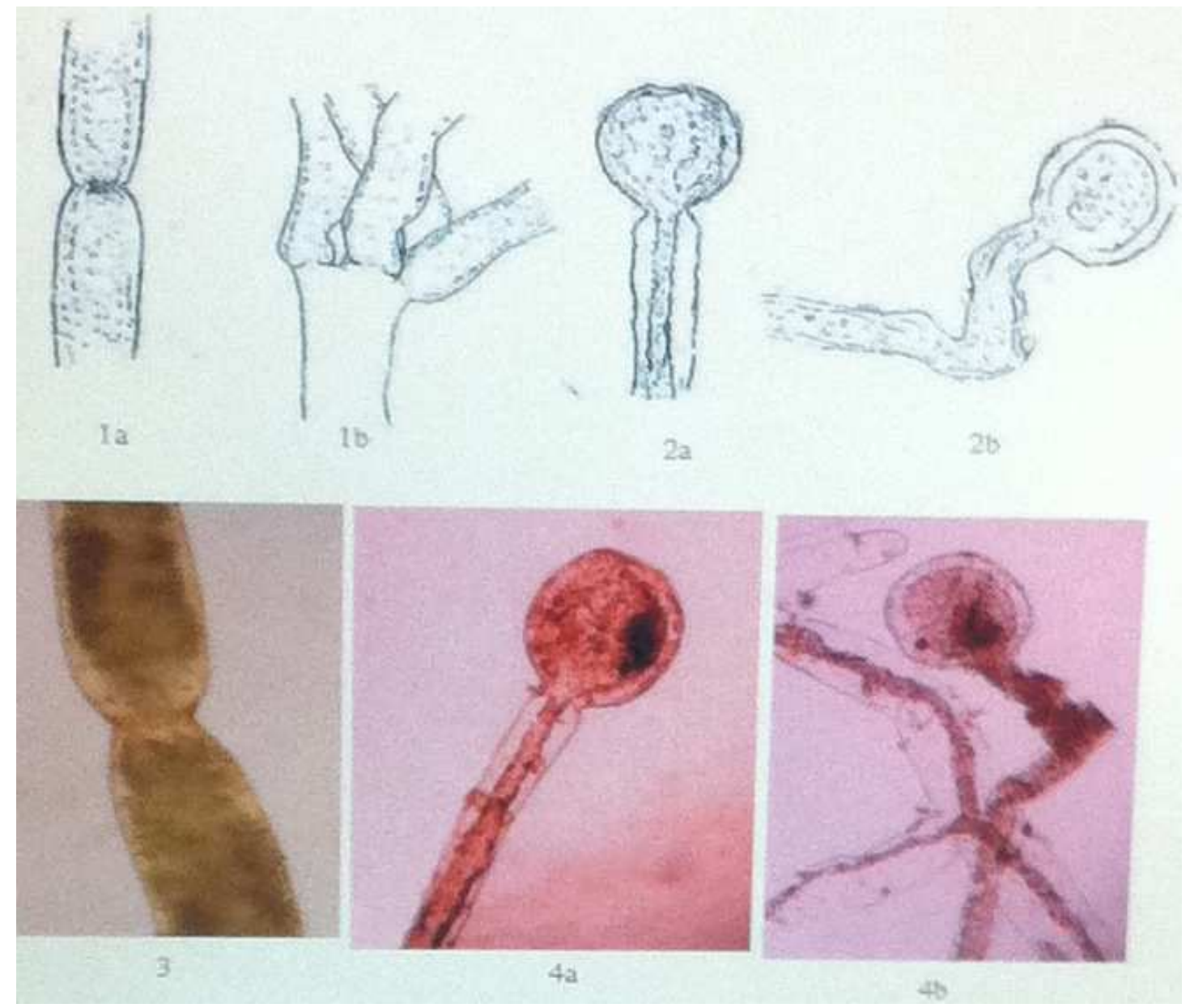

Plate 1. Figs. 1-4: 1a. Dichotomosiphon tuberosus, constricted filament, 1b. Upper portion of filament showing constrictions between dichotomies, 2b. Vaucheria sessilis with oogonium, 3. Dichotomosiphon tuberosus, constricted filament, 4a, 4b. Vaucheria sessilis with oogonium. 
Genus: 2. Vaucheria D.C.

Order: Heterosiphonales

Family: Vaucheriaceae

Genus: 2. Vaucheria D.C.

2. Vaucheria sessilis (Vauch.) D.C., Flore Francaise 2: 63. 1805. (Pl. 1, Figs. 2a, 2b. and Figs. 4a, 4b.)

Randhawa, in Arch. f. Protistenk 92: 538. fig. 1. 1939.

Venkataraman, Vaucheriaceae 68. fig. 46a. 1961.

Kant and Gupta, Algal Fl. Ladakh 117. pl.65. figs. 2a, b. 1998.

Gupta, Algal Fl. Dehradun Dist. Uttaranchal 142. pl. 44, figs. 2a-b. 2005.

Vauchria caespitosa Vauch. 1805.

Description: Thallus slightly yellowish green, forming velvety mats, compactly interwoven on submerged bottom muddy soil; filaments attached by delicate colorless rhizoids; filaments monoecious, irregularly branched, cross wall absent (except during reproductions), coenocytic, 453.0-498.0 $\mu \mathrm{m}$ long and 58.0-68.2 $\mu \mathrm{m}$ broad; chloroplasts numerous, ovoid; pyrenoids absent; antheridia between two oogonia, hook shaped to circinate, 63.0-95.0 $\mu \mathrm{m}$ long and 32.2-32.67 $\mu \mathrm{m}$ broad; oogonia two which are ovate, sessile, slightly oblique, 83.0-91.0 $\mu \mathrm{m}$ long and 62.0-65.6 $\mu \mathrm{m}$ broad; beak oblique; oospore dark green, completely filling the oogonium, 75.0-94.7 $\mu \mathrm{m}$ long and 52.0-65.7 $\mu \mathrm{m}$ broad.

Habitat: Free-floating and attached to bottom muddy soil of pond at Tribeni and Balarambati. West Bengal, India.

Collection No: 811, 812, 1012

Date: 03.01.2011, 07.02.2011

Significance: Primary producer and a component of this aquatic food chain.

\section{ACKNOWLEDGEMENTS}

Authors are grateful to University of Kalyani for pursuing research programme. N. Haldar is also grateful to Head, Principal, Raja Peary Mohan College, Uttarpara, WB and Dr. R.K. Gupta, Scientist-C, BSI, Howrah, WB for their valuable guidance and co-operations.

\section{REFERENCES}

Ampili, P. and M.V.N. Panikkar. 1994. Occurrence of Dichotomosiphon tuberosus (A.Br.) Ernst. from Kerala. Bionature 14:5152.

Chohan, J.G. and R.J. Patel. 1957. Occurrence of Dichotomosiphon tuberosus (A.Br.) Ernst in North Gujarat. Vidya 1:37-41.

Dey, N. 2007. Vaucheria sessilis (Vauch.) D.C.new record from Darjeeling district, W.B. Environ. Ecol. 25:931-933.

Jha, B.C. and D.K. Kaushal. 1983. Algae from Gobindsagar, Himachal Pradesh. Phykos. 22:141-143.

Khan, M. 1985. Algal flora of Sultanpur (U.P), India. Phykos. 24:52-57.

Mukhopadhyay, A. and R. Pal. 2004. Dichotomosiphon erecta sp. nov. a new species from brackish water region of West Bengal. Indian Hydrobiol. 7:7-11.

Pal, T.K. and S.C. Santra. 1984. New additions to algal flora of Murshidabad, W.B. Phykos. 23:139-141.

Sarma, P. 1973. Addition to the fresh water algae of New Zealand-1. A note on the species of Vaucheria from Great Barrier Island. Tone 19:167-173.

Sarma, P. and V.J. Chapman. 1975. Light and scanning electron microscopic study of Vaucheria pacnyderma Walz. collected from Auckland, New Zealand. Nova Hedwigia 26:233-250. 
Sharma, R. and S.S. Moghe. 1957. On the occurrence of Dichotomosiphon tuberosus (A.Br.) Ernst from Indore (M.P). Curr. Sci. 26:254-256.

Sarma, T.A. and R.S. Rattan. 1990. Genus Vaucheria in India. Nova Hedwigia. 51:489503.

Singh, S.J. and Y.B.K. Chowdhary. 1973. Some observations on the cytology of Dichotomosiphon tuberosus (A.Br.) Ernst. Phykos. 12:8-10.

Sinha, B.D. and N.K. Srivastava. 1980. Algal flora of Balmikinagar, Bihar. Phykos. 19:171-174.
Srivastava, O.N. and M. Srivastava. 1984. Vaucheria debaryana Woronin- A new record from Bihar. Geobios New Rep. 3:52.

Srivastava, O.N., M. Srivastava and U.S. Prasad. 1987. Record for India, Vaucheria crenulata Prescott. Acta Botanica Indica 15:104.

Venkataraman, G.S. 1961. Vaucheriaceae. ICAR, New Delhi, India, pp. 1-112.

Verma, B.N. and M.P. Verma. 1978. New record of Dichotomosiphon tuberosus (A.Br.) Ernst var. from Bihar. Phykos. 17:59-62. 